\title{
RELIGIOUS ARCHITECTURE IN PÉCS DURING THE PERIOD OF OTTOMAN HUNGARY
}

\author{
Róbert MAJOR, ${ }^{1}$ Balázs KÓSA ${ }^{2}$ \\ University of Pécs, Faculty of Engineering and Information Technology, Pécs, Hungary \\ ${ }^{1}$ major.robi1192@gmail.com \\ ${ }^{2}$ kosa.balazs@mik.pte.hu
}

\begin{abstract}
In today's increased pace of life there are some things with incomparable meanings that we are getting too used to. Because of this, architects today play a very big role in the defense of the legacy of our architecture. It is our duty and responsibility to keep defending this legacy, but not stop at just the level of simple preservation. The city of Pécs is filled with architectural remains from different time periods, but most of all buildings from the era of Ottoman Hungary. This architectural heritage was left from one of the bloodiest time periods from the history of our country, and it has become a symbol for the city. In the shadow of the Ottoman Empire, Pécs became an important trading and cultural center, being a bridge between east and west, north and south. While some of the buildings left from this era were brought to public awareness, a lot of them were forgotten, and only a few people know about the architectural treasures the city holds.

In this paper I would like to highlight some of the forgotten Ottoman heritage, focusing on the religious buildings. As a conclusion to this paper, I would like to present an architectural plan to bring attention to these buildings.
\end{abstract}

Keywords: historic buildings, Pécs, turkish, sacred, tomb of Idrisz baba, mosque.

\section{Introduction}

The monuments and relics surviving from occupied Pécs form the personality of the city, even today serving as an emblem. Despite their immeasurable value, some are in really bad condition and lacking function. The cultural difference hardens even more considering the importance their builders intended for them. In our study we examined several of these monuments including their conditions and the deeper cultural habits and customs around which they were built. This information forms the foundation of a design project for a visitor centre dedicated to these almost forgotten monuments.

\section{The occupied Pécs}

In $1541 \mathrm{AD}$ the Ottomans occupied Buda and besieged Pécs. The captain of the city's defence, Lukács Székely had to face the fact that the defensive system of the city was simply not up to the task of resisting the Ottoman army. In $1542 \mathrm{AD}$ they opened up the city gates for the Ottomans without a single drop of blood. The Ottoman Empire ruled Pécs for the next 143 years.

Documents state that the city under occupation had 4 Ilié (building complexes), 17 places for worship, 5 religious' colleges, 11 elementary schools, 6 monasteries, 3 bathhouses, 47 wells, 3 Inns, a marketplace and bazaar, 2 tombs and countless establishments for entertainment. These were the core buildings of the city in this period.

\section{The monuments of Pécs from the Otto- man period}

\subsection{Mosques}

\subsubsection{Mosque of Pasha Hasszán Jakováli}

The mosque of Pasha Hasszán Jakováli Jakovali is one of the most preserved monuments from the Ottoman period in Middle Europe. Located 
in the Kórház Square wedged between two buildings, almost hiding from the sight of those who are not aware of its existence. Even today it's a functioning place of worship and a museum which makes it an important centre for the Muslim people of Hungary.

The mosque was built in the middle of the XVI. century and survived with only small works of restoration so that even today the original design is well preserved (for example, its windows ending in arches, the dome and the minaret.

\subsubsection{The mosque of Pasha Kászim Gázi}

The mosque of Pasha Kászim Gázi is the largest religious building in Hungary. Located in the main square, in the Széchenyi square it is one of the most renowned symbols of Pécs. After several reconstructions it has regained its original face, although with a different function as a catholic church.

\subsubsection{The mosque of Pasha Ferhád}

The mosque of Pasha Ferhád is in the worst condition compared to the others. Its ruins came to the surface in the demolition works of one of the most iconic building in Pécs: the Civil Casino. The ruins contained the foundation, some of the arches and some details of the structures of the windows. This mosque represented great value for the dervishes. After the occupation ended the mosque was handed over to the Dominican Order. The Order did not pay attention to the maintenance of the building and it was used as a granary. Soon it started to crumble. The lot which the ruins are located on is in private hands, away from the public and overgrown with grass.

\subsection{Wells}

In the Islamic culture the wells served multiple functions in religious purposes and were important in public and social life, all linked to the water that the well provided. Knowing this it's not so surprising that all the cities under Ottoman rule started to build wells. Of course, this is true in the case of Pécs as well. Several wells were in use in the city. Worth mentioning is the well of Idrisz Baba which is a really accurate reconstruction of the original one, and in the same location that the original one was founded. Today it can be seen in Káptalan Street.

\subsection{Cemeteries, Tombs}

The burial sites in Pécs differ in the way that they reflect the different cultures that lived there. Cemeteries from the Ottoman period are hard to locate accurately because the majority of these were destroyed by the growing city. Archaeological studies show that the city had several cemeteries, such as the burial sites next to the mosques mentioned above. Relics of Ottoman cemeteries are also found from excavations of Szigeti Street and from the surroundings of the Árkád mall. It is believed that the biggest cemeteries were located in the line of Rókus Street and outside of the gates Szigeti and Budai.

\subsubsection{The Tomb of Idrisz Baba}

One of the greatest monuments, in terms of Ottoman burial customs and architecture, is the Tomb of Idrisz Baba. It consisted of a building above the surface, probably as one section of the cemetery of Rókus Street.

Idrisz Baba was a saint, a member of the Bektasi Order. Several miracles are associated with his life. His tomb was built a few years after his death as a place for pilgrimage. The exact year is still not known but according to documents it was built in the early period of the XVI century.

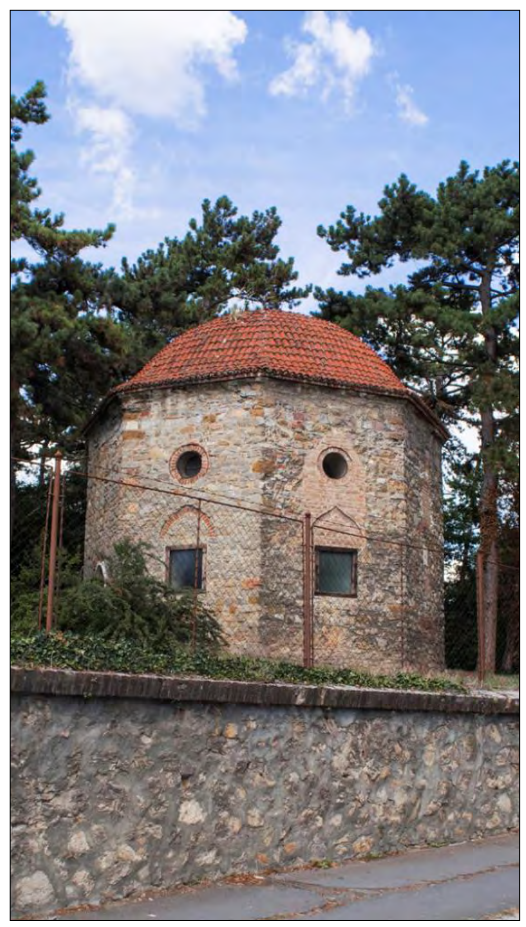

Figure 1. The Tomb of Idrisz Baba 
After the occupation ended, the use of the tomb went through many changes. It has been used as a chapel, hospital, and as storage for gun powder. In the XX century it was re-established as a monument, and has remained so ever since. Renovation and studies have taken place: The site and the building itself was the focus of archaeological research and an overall structural survey was carried out in the 60 's.

The building itself is an octagonal shaped structure made of stone covered with a dome. The walls have not been covered with mortar: not a single marking has been found so restoration is not possible. The „naked” wall however shows us the difference between periods. It can be visited by appointment.

\section{Proposal for improvement on the tomb of Idrisz Baba}

A project has already been completed with the concept of a public park around the tomb. Aiming to create a park with communication with it is surroundings. The goal was to design a space around the building of the tomb which uses this monument as its central attraction. It achieves this with a respect it deserves. We have tried to grasp on that idea. To achieve this goal we used symbols from the Quran. This sign was the „rub el hizb”. In the Quran each chapter ends with this 8 -armed star symbol. The tomb lays in the center of the star which made it possible to create a terraced structure around the tomb. By studying the Islamic costumes we further used symbols such as water (religious bathing), vegetation (species, other flowers specifically bind together with Islamic culture), and of course the colours (the Islam and ottoman cemeteries often used white as a main colour). With this knowledge I cooperated with Dr Balázs Kósa and together we managed to design an early form of a building that, as mentioned above, uses the tomb as its center and completed the park with further functions. We studied for local Ottoman values and characteristics keeping in mind the locations of the known monuments as well. In addition to the recreational zone, the public space plan has been expanded and developed with the concept of information and communication.

We found it important not to focus on the new building but on the monument itself. Thus, on the basis of the existing work, the plan of a public square where the main traffic lanes would be approach the Tomb started to emerge. Flower beds and point like water surfaces appeared near the rest areas.

The idea of a terraced-like park suddenly expanded with the concept of an underground structure. Eventually, we developed this thought and soon an underground exhibition space formed with the Tomb's extension in the centre.

The entrance was imagined with a drawn out structure (the downhill is provided by a ramp and a stairway line), which descends steadily and guides the visitors into the already mentioned exhibition space. We planned that only this „neck” like structure would appear on the surface and indicate our new building underground. Two different thoughts emerged as surface cover: the first thought was the front of the white concrete walls, the second was lightly polished stone slabs. The front door was perceived as a perforated Corten steel door. It is planned that behind the Corten plate a surface of LED lighting would be placed making the front door working as a simple projector. The natural illumination of the entrance to the space is given by a glass slab with water on top. We intend to display the water inside the interior, so this way tiny veins of light run into the exhibition space on top of the staircase and ramp. In the planned exhibition space the first thing the visitor can see is the shape of the tomb as an interesting piece of art. In addition, a combination of point-like, ring-shaped skylights and platforms bring the visitor to a modern exhibition space. A

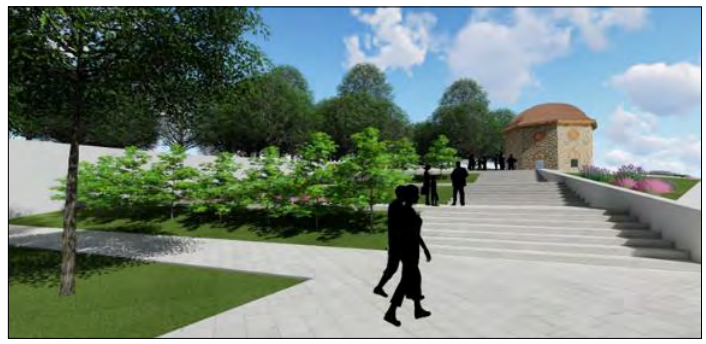

Figure 2. Entrance of the planned park

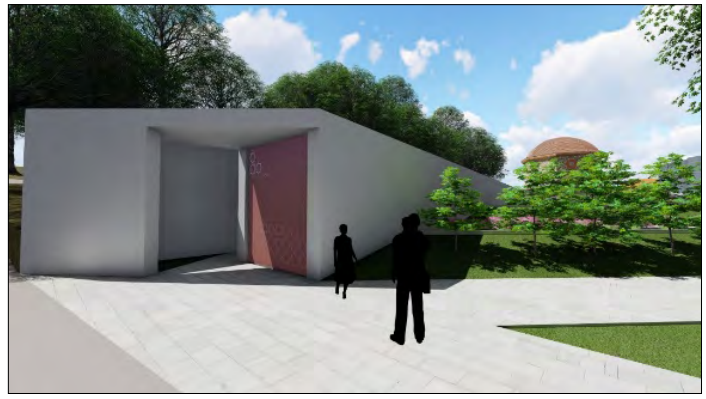

Figure 3. Entrance of the plannned visitor centre 


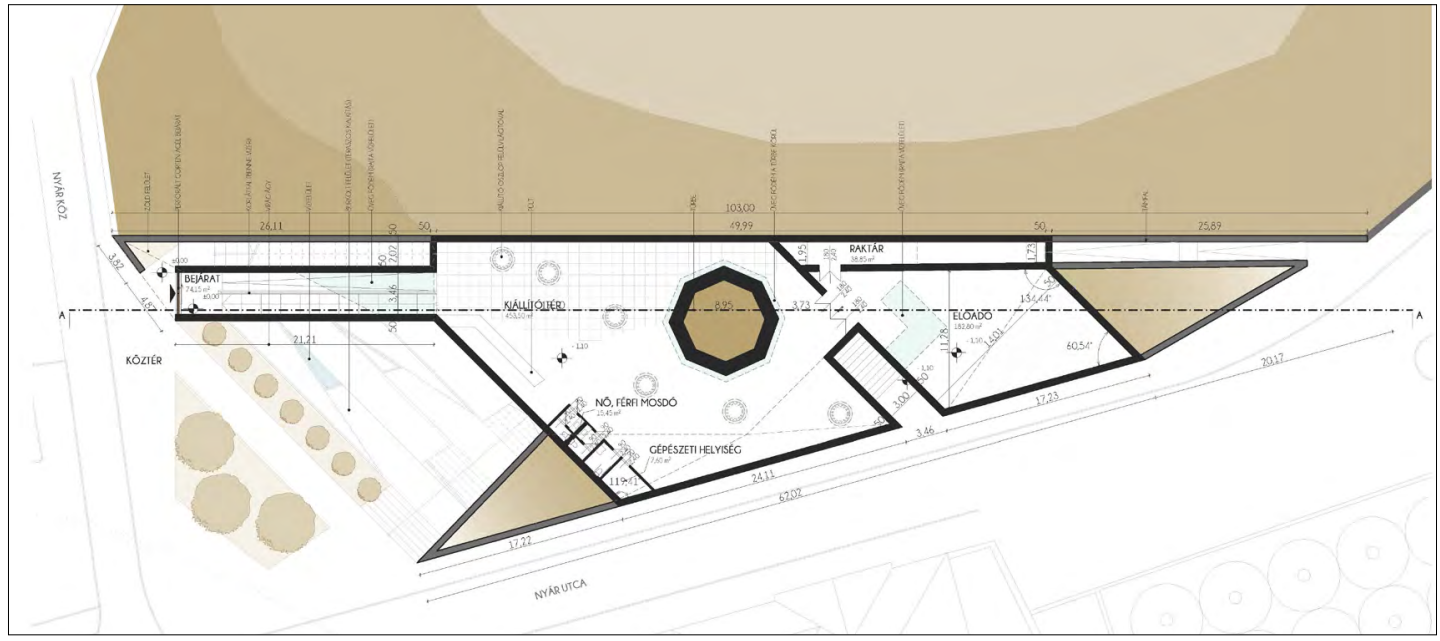

Figure 4. Floor map of the planned visitor centre

reception zone has also been added to this space (appearing as a counter which also functions as a cashier point and a „museum shop”) as well as social rooms.

In order to make it interesting for all ages and to provide the building with an additional educational function, a lecture space was created in the eastern part, which would be specially equipped with virtual reality tools. Instead of traditional museology, which would not be tempting enough, modern technology would attract more attention that would not only benefit tourism but also local education. There are courses in each of the nearby university faculties that would benefit from such a space. In addition, things that might need more tour guides and can be explained in a difficult way can be presented to the general public much more easily. With the right tools you can take the visitor to Pécs through different ages and rediscover the old castle in its former glory. Nowadays to create a virtual space from even another age to is considered an easy task. From a touristic point of view, the building can be the starting or the ending point of a thematic Turkish tour, where everyone benefits from the tools of virtual reality, pre-information or answers to their questions.

\section{Acknowledgement}

Supported by the ÚNKP-18-1-I-PTE-186 New national excellence program of the Ministry of Human Resources Capacities.

\section{References}

[1] Varga S.: Irem kertje. Pécs története a hódoltság korában 1526-1686. 1526-1686 Pécsi Püspöki Hittudományi Főiskola, Pécs, 2009. 59-64.; 109-124; 163-170.

[2] Sudár B.: A pécsi Idrisz baba-türbe. Forster Gyula Nemzeti örökséggazdálkodási és szolgáltatási Központ, Budapest, 2013. 9-70.

[3] Hancz E., Varga Sz.: Pécs mindennapjai a török félhold alatt. Pannon Kultúra Alapítvány - Janus Pannonius Múzeum; Pécs, 2013. 39-65. 